\title{
Attitudes of Junior National Team Athletes towards Opponents: Ideology/Morals
}

\author{
İlyas Görgüt ${ }^{1}$, Erkut Tutkun ${ }^{2}$ \\ ${ }^{1}$ School of Physical Education and Sport, University of Dumlupınar, Kütahya, Turkey \\ ${ }^{2}$ Faculty of Sport Science, University of Uludag, Bursa, Turkey \\ Correspondence: Erkut Tutkun, Faculty of Sport Science, Unıversity of Uludag, Bursa, Turkey.
}

Received: October 8, 2017

doi:10.11114/jets.v5i12.2685
Accepted: October 30, $2017 \quad$ Online Published: October 31, 2017

URL: https://doi.org/10.11114/jets.v5i12.2685

\begin{abstract}
Competitions between countries occur in every field, from science to industry. This competition is inevitable in the field of sports, which is the greatest feature of publicity in countries, one of the tools of getting political advantage and the greatest focus of global capital. This competition, which is seen in the fields of sport, sometimes becomes extreme and situations arise which are far from reflecting the nature of sports. Especially the efforts of athletes to represent their countries in the best way sometimes cause them to behave inappropriately to their opponents. Thus, the purpose of this study is to find out whether athletes' being on the national team has any effects on their moral structure and to find out whether the attitudes they show to their opponent during competition are ideological or moral. Phenomenologic design was used in the study which was prepared with qualitative research method. The sample group of the study consists of 10 athletes in the junior national team who were determined with maximum variation sampling method. Individual interviews of an average of 10-12 minutes were conducted with the athletes within the context of semi-structured interview technique. The participants were informed that the interviews would be voice recorded and their expressions would later be converted into text to avoid data loss; the interviews were recorded after the necessary permissions were taken. Descriptive and content analysis method were used to analyze the expressions converted into text. Analysis results showed that the athletes stated that being on the national team had positive effects on moral structure due to motivating factors such as representing one's country and being role models and that they were led by their moral structure while competing with their opponents.
\end{abstract}

Keywords: junior, national, athlete, moral, opponent, ideology

\section{Introduction}

Some of the characteristics that people have bring them to the forefront and enable them to be respected by the society. These characteristics include being trustworthy, being tolerant to people, not insulting people, being respectful to old people, not showing language, religion, race and gender discrimination to people under any circumstance; in short, being moral. According to Çitemel (2010) morals is an individual's cognitive structure which includes all of the attitudes and behaviors a person has innately or has acquired as a result of his experiences during a life time; reasoning consciously between fair-unfair, right-wrong, good-bad; making personal decisions and getting into act. Drawing on from Kohlberg, Passini (2014) defines morals as a general or universal cognitive system that causes character change through the integration of gradual differentiation and social knowledge. A person's moral structure can be influenced by the environment or society he/she lives in. Changes, which occur with the age of technology unavoidably, create influences on morals. The method individuals resort to in order to resolve negations and to realize the principle of a healthy life and a healthy society is the socialization of individuals under suitable conditions and through suitable individuals. The most important tool that can create this socialization is sports.

As the consciousness of healthy life increases in society, more people start doing physical activity and sports. In addition to meeting their physical needs by taking part in individual or team sports, individuals also meet their emotional needs through some factors such as communicating with friends, meeting larger masses and the feeling of famousness that comes with success. In their psychology research, Danioni et al. (2017) stated that people were greatly interested in sports recently since sports had an effect not only on physical competence but also on the development of all competences, mainly humanitarian values and recent researches emphasized that sports helped young people to 
internalize the values of responsibility, honesty, suitability and ambition. These motivation factors carry individuals to the farthest points they can go. Athletes try hard to reach the top in their sport, to be on the national team and to represent their country in the best way possible within the context of their goal to be a national team athlete. However, sport is internationalized, professionalized, commercialized and globalized. Thus, in sports, parties compete with each other within the agenda determined by international companies and global non-governmental organizations with a significant rate (Kew, 1997, p. 51). In short, individuals' ideologies compete. These structures determine people's attitudes to each other. Burton (1995) defines ideology as sets of beliefs and values summarized with a specific point of view about the world and power relationships between people and groups. Şahin (1998) advocates that some ideologies such as pragmatism, individual competitiveness, chauvinism and nationalism characterize sports. Due to these ideologies which occur to a great extent as a result of marketing operations and commercialization pressures of international investment, bad situations occur such as selfish and aggressive individualism in sports environments, fierce competition, trickery of equal opportunities, elitism, sexism and militarism (cited from Talimciler, 2005, p. 23). Such negations are seen frequently in national teams where countries' ideologies step in, that is, in international platforms where competitions observed between countries.

After the First World War, sports really became international. Following that day, politicians began to appreciate the place of sports in their policies of publicizing and showing their political ideologies and in being a mediator of national values (Arnaud and Riordan, 2013). Sport has been supported bidirectionally in order to end communal subversions which threaten national unit (Allison, 2005). According to Tomlinson and Young (2006), sports events which celebrate the body and physical culture have been directed by political and ideological reasons for many years from Ancient Greece and Roman civilization to early period European and modern western societies. Political exploitation and cultural and economic consequences of sports games are seen as critical indexes to the globalization of both the media and sports. Holmes (1994) mentions three points within the relationship of sports and ideology. Firstly, since sports can directly provoke social conflicts, it is seen as a concept that creates discrimination and with this discrimination it is seen as a social safety valve that can prevent physical violence. Secondly, since sport includes education and physical fitness, it creates resources that can be used politically. French nationalist politicians who thought that they could define themselves with sportive heroism and success during the times of war promoted sports due to discipline and military skills they received. Thus, politicians are always ready to communicate with a successful athlete. Lastly, because of being used as a metaphor for political values of the society, sport is accepted to be a significant representative of political socializing. Especially the Soviet Union and Eastern European countries have greatly invested in sports as a medium for their national and international positive image. In addition, a great majority of nations view sports as a way to symbolize their acceptance in international society. Nations even use international sports organizations in boycotting other countries the behaviors of which they do not approve of (Allison, 2005).

Sport, which has become a significant medium of global capital as a result of the benefits it provides to the individual and the great mass it reaches, is starting to become a global problem as a result of the efforts of countries to outclass other countries and to have themselves accepted. Tensions between countries also show themselves in war and international competitions and cause athletes to choose between morals and ideology. Especially the rivalry between countries, together with the pressure of winning in any case, is also reflected to the athletes of the country and the athletes compete with the reasoning that they can go to any lengths to win. This situation causes immoral consequences such as athletes' showing their rivals attitudes which are not suitable for fair play and using illegal substances and cause the athletes to get away from living the essence of sports and to be stuck in between the cycle of becoming professional and globalization. Thus, negative situations seen in sports environments become one of the subjects dwelt on by researchers. To be more specific, especially the issue of sport ethics comes to the forefront. It is necessary to find out the source of the problem in issues such as doping, racism, politics, ideology, etc. and to offer solutions so that sports can be done duly. Although there is no consensus in our country in terms of sport ethics, researchers mostly focus on the concept of doping. There are not many studies conducted on the subject of ideology, which guides athletes' performances and causes negative situations for them. Thus, it is thought that this study will support the country's sport policy by finding out whether ideological attitudes are effective on the moral structures of junior national team athletes or whether these athletes show ideological attitudes while competing with their rivals.

\section{Method}

This study is a qualitative study prepared to find out whether the athletes' being on the national team influences their moral structure and to find out whether they approach their rivals ideologically or morally during competitions. Qualitative research is defined as a type of research which follows a qualitative process to present cases and events in their natural environment in a realistic and integrative way by using qualitative data collection methods such as observation, interview and document analysis (Yıldırım and Şimşek, 2013, p. 45) and as an umbrella term which includes techniques aiming to reach terms to define, solve, comment and interpret (Merriam, 2013, p.). The study used 
phenomenology design. Phenomenology is a research method with specific features and a philosophical content. This method includes the research of individual universe, that is, individual experiences, individuals' perceptions and the meanings they attribute to events (Baş and Akturan, 2013).

\subsection{Research Group}

The research group of the study consists of 10 athletes in junior national teams of different sport branches. Maximum variation sampling method was used to assign the participants. In this method, the purpose is to form a relatively small sample and to reflect maximally the variety of the individuals that can be a side of the problem studied in this sample. This method is not for making generalizations; on the contrary, it is for trying to find out whether there are common or shared cases between situations that vary and to present the different dimensions of the problem according to this variation (Yıldırım and Şimşek, 2013, p. 136). Information about national team athletes who participated in the study is given in Table 1.

Table 1. Information about the participants

\begin{tabular}{llllllll}
\hline $\begin{array}{l}\text { Participant } \\
\text { Code }\end{array}$ & Gender & Age & Branch & $\begin{array}{l}\text { Type of the } \\
\text { national team }\end{array}$ & $\begin{array}{l}\text { Experience in } \\
\text { national team }\end{array}$ & the & Degrees \\
\hline 1 & M1 & Female & 19 & $\begin{array}{l}\text { Arm } \\
\text { wrestling }\end{array}$ & National B & 3 Years & $\begin{array}{l}2^{\text {nd }} 3^{\text {rd }} \text { in Turkey, } 6^{\text {th }} \text { in } \\
\text { Europe }\end{array}$ \\
2 & M2 & Female & 19 & $\begin{array}{l}\text { Arm } \\
\text { wrestling }\end{array}$ & National B & 3 Years & $\begin{array}{l}1^{\text {st }} \text { in Turkey, } 1^{\text {st }} \text { in Europe, } \\
3^{\text {rd }} \text { in the world. }\end{array}$ \\
3 & M3 & Male & 21 & Athleticism & National C & 4 Years & $1^{\text {st } \text { in Turkey }}$ \\
4 & M4 & Female & 24 & Handball & National A & 8 Years & - \\
5 & M5 & Male & 21 & Badminton & National C & 3 Years & $1^{\text {st } \text { in Turkey }}$ \\
6 & M6 & Male & 26 & Basketball & National B & 7 Years & $3^{\text {rd } \text { in Europe }}$ \\
7 & M7 & Male & 24 & Volleyball & National A & 4 Years & Balkan Champion \\
8 & M8 & Female & 20 & Judo & National C & 4 Years & $7^{\text {th }}$ in Europe \\
9 & M9 & Female & 20 & Football & National B & 6 Years & $1^{\text {st }}$ and $4^{\text {th }}$ in the world \\
10 & M10 & Female & 21 & Kickboxing & National A & 4 Years & $1^{\text {st } \text { in Turkey }}$ \\
\hline
\end{tabular}

\subsection{Data Collection Process}

Structured interview technique was used to find out the effects of being a national team player on the athletes' moral structure and to find out how they approached the players of the opposing team during competition. After the questions, which were planned to be asked to the participants were edited, they were checked by experts for both content and structure validity and it was decided to ask 2 questions. First of all, the athletes were reported that the data would be voice recorded both to prevent data loss and time loss and the records would be kept by the researcher. After the participants' approvals were taken, face-to-face interviews were conducted with the recorder. The interviews lasted for an average of 12 minutes. The questions in the interview are given below.

Question 1: How does the athlete's being on the national team influence his/her moral structure?

Question 2: How do you approach your rival during a competition? Are you guided by your ideological structure or your moral structure? Can you explain your reasons?

\subsection{Data Analysis}

The interviews recorded by the researcher were turned into text with computer. The athletes were coded as M1, M2, M3, M4, M5, M6, M7, M8, M9 and M10. Descriptive and content analysis were conducted on the texts. Categories were formed in terms of the effects of athletes' being on the national team on their moral structure and their views about their attitudes to rivals. In order to reach categories, content analysis was included first, while descriptions and quotations were included for reliability.

\section{Results and Interpretation}

This section presents the answers to the questions which were asked to national team athletes in the form of categorical charts obtained from statistics program and content and descriptive analyses are included. 
The participants were asked the question "How does the athlete's being on the national team influence his/her moral structure?". The athletes expressed their thoughts about whether being on the national team had an effect on their moral structure.

Table 2. Athletes' thought about the effect of being on the national team on their moral structure

\begin{tabular}{|c|c|c|c|}
\hline Descriptive Category & Sub category & Codes & Definition of the Codes \\
\hline \multirow{6}{*}{$\begin{array}{l}\text { Being on the national team } \\
\text { Moral structure }\end{array}$} & \multirow[t]{2}{*}{$*$ Negative effects } & $\checkmark \quad$ Pressure & $\begin{array}{ll}* \text { Family } \\
\text { Coach } \\
\text { Win } \\
\text { Supporters } \\
\end{array}$ \\
\hline & & $\begin{array}{ll}\checkmark & \text { Character } \\
\text { Change }\end{array}$ & $\begin{array}{ll}* & \text { Success } \\
* \quad \text { Popularity }\end{array}$ \\
\hline & \multirow[t]{3}{*}{ *Positive Effects } & $\checkmark \quad$ Personal & $\begin{array}{ll} & \text { Being respected } \\
\text { - Supporting young athletes } \\
\text { Using being on the national team positively } \\
\text { Personal differences } \\
\text { A decent character } \\
\text { Role model }\end{array}$ \\
\hline & & $\checkmark \quad$ National & $\begin{array}{ll}\quad \text { Flag } \\
\quad \text { National team uniform } \\
\quad \text { Representing the country }\end{array}$ \\
\hline & & $\checkmark \quad$ Environmental & * Society \\
\hline & *No effect & $\begin{array}{ll}\checkmark \text { Experience } \\
\end{array}$ & \\
\hline
\end{tabular}

In Table 2, athletes expressed that being on the national team had effects on moral structure; they stated that especially representing the country, wearing the national team uniform and characteristics to show in society and being a role model supported moral structure positively. In addition, they stated that pressures of the family and coaches to win, success and popularity brought by being on the national team could influence a person's character negatively, while they stated that there would be no effect with experience. Below are some of the answers given by national team athletes to the related question.

M1: Wearing the national team uniform and representing one's country are different; however, being on the national team does not have an effect on the moral structure because morals is something that a person has to have. I think about the contest between my rival and me not ideologically, but morally, because there may be wars and problems between countries; however, when you are in a competition, they remain in the background and not influence my moral structure.

M5: .....This situation runs in the family and the coach. Some people can do anything to win and this completely results from the environment they come from, because the athletes have spent 8-10 years and become professional. Within this period of time, athletes take as example what they see from their coaches and friends. If there are immoral behaviors during training, the athlete takes these as example and can show these behaviors.

M8: Changes can be seen in the way of talking and behaving in some people as their popularity increases. This is completely personal.

M8: There may be people who were modest before being on the national team and getting success but have become different later. This is completely personal.

M9: National team athletes are role models. The athlete should think about the national team uniform and not show improper behaviors. Thus, being a national team athlete influences morals positively because athletes feel the obligation to be so.

M10: After being a national team athlete, the flag and the star and the crescent become very important for an athlete. Once you get in the team, you understand better what the flag means, national team means. Although the family and the character are also involved, these have more influence and develop morals more.

The athletes who participated in the study were asked the question "How do you approach your rival during a competition? Are you guided by your ideological structure or your moral structure? Can you explain your reasons?" National team athletes expressed their views about whether they were guided by their ideological or moral structure. 
Table 3. Athletes' views about approach to rival during a competition

\begin{tabular}{|c|c|c|c|}
\hline $\begin{array}{l}\text { Descriptive } \\
\text { Category }\end{array}$ & Sub category & Codes & Description of codes \\
\hline \multirow{9}{*}{$\begin{array}{l}\text { Approaches } \\
\text { to rival }\end{array}$} & \multirow{5}{*}{ *Moral approach } & $\checkmark$ International & * Problems between countries \\
\hline & & $\checkmark \quad$ Positive support & $\begin{array}{l}* \quad \text { Circle of friends } \\
* \quad \text { Coach }\end{array}$ \\
\hline & & $\checkmark \quad$ Individual & * Positive motivation \\
\hline & & $\checkmark \quad$ Sportive & * Fair play \\
\hline & & $\checkmark \quad$ National & $\begin{array}{l}\text { Representing the country } \\
\quad \text { National team uniform }\end{array}$ \\
\hline & \multirow{4}{*}{$\begin{array}{l}\text { *Ideological } \\
\text { approach }\end{array}$} & $\checkmark \quad$ Trauma & $\begin{array}{ll}* & \text { Historical events } \\
* & \text { Wish for revenge }\end{array}$ \\
\hline & & $\checkmark \quad$ Negative support & Circle of friends \\
\hline & & $\checkmark \quad$ Pressure & * Coach \\
\hline & & $\checkmark \quad$ Rival's approach & * Ideological \\
\hline
\end{tabular}

In Table 3, it can be seen that the athletes stated that their moral structures were influential in their approaches to rivals during a competition and that athletes who were positively supported by their circle of friends and coach approached their rivals within the context of fair play. However, they have also stated that ideological approaches are also shown due to historical events, coach's pressure and the rival's approaches. Below are some of the answers given by national team athletes to the related question.

M1: I think about my contest with the rival not ideologically, but morally because there may be wars and problems between countries; however, during the competition these remain in the background and do not influence my moral structure.

M5: One's environment and coach are influential. If the coach says something like "we have to beat this country", one should apply the reason of "all is fair to win the game". However, if the coach says things like "you can win, what matters is to compete, you can do it", and if you have spent a training period in such an environment, you can think that your opponent is also an athlete and the same things can happen to him and thus show moral behaviors.

M6: Due to a sad event that happened to our ancestors, I did not think morally in the game we played with ............ :I thought ideologically. Our rivals were already reflecting their hate, swearing and doing everything immoral. After all, there was a different case between us, I mean I did not have morals in that game.

M8: To be honest, however much I want to stay within the moral framework, I approach ideologically to the athlete of a country we have problems with. I take revenge.

M9: We played a game with ......, during that time, the relationships between Turkey and ...... were bad. The coach said things like "you have to play differently with this team, you have to score the highest." The opponent team did so, too. Everyone was hitting and getting injured. I cannot help but get angry, I cannot approach morally when we have to win.

M10: Even if I want to approach ideologically, I have to move within Fair Play since I represent my country there. Because I represent Turkish nation I cannot exceed my authority and I have to play the game according to its rules.

\section{Conclusion and Discussion}

Sport which is seen as a medium of publicity and domination by countries and national team athletes are unavoidably in the center of some negations. Especially being directed along with the goals of capital and professionalization causes sport to lose its nature. It will be useful to learn how these negations are assessed in terms of the athletes' points of view in order to take precautions. Thus, this study was conducted to find out whether being a national team athlete has an influence on their moral states and whether the motivating power against a rival during a competition is ideological or moral. The following conclusions were reached as a result of the interviews with the athletes.

Being a national team athlete, being respected, transferring experiences to young athletes who will represent our country in the following years and supporting them to guide them have a positive effect on moral structure. In addition, having behaviors which will be respected by the environment for being a national team athlete, the effort to show a decent character, the goal of being a good role model especially for young athletes have a positive effect on moral structure. Representing one's country in the best way possible and wearing the national team uniform with honor also have a positive influence on moral structure. According to Krüger (1993), international competition is required to provide national prestige through elite sports and to show that one is superior to another. As mentioned by Arnaud and 
Rordan (2013), sport is considered to be a great power by nations to protect their togetherness, to maintain continuity and not to lose prestige. Firica (2012) advocates that sport is seen both as a source of identity and as a tool for social integration in fighting discrimination and racism in the European Parliament and that European Union uses big sports activities to develop its own image and to generalize its common discourse. Thus, at the point of representing the country and being superior to other nations, elite sports, that is, competitions by national team athletes, are important for countries. National team athletes are very important for this reason. In athletes who want to see their country in the best places, features such as showing a role model approved in the society, interacting with athletes who will represent the country in the international arena in the following years and supporting them come to the forefront. In line with these goals, supporting moral structure in national team athletes and working hard for this can have a positive effect on the long term political targets of countries and their efforts to be better than other nations.

A great number of factors, such as family, coach, circle of friends and supporter group have an influence on the performances of national team athletes. According to Eccles and Harrold (1991), families have an influence in all of the decisions athletes take during their lives and parents' expectations are determiners of many decisions such as participation in sports, intense training and performance. According to Wylleman and Lavallee (2004), in the sports career development of an athlete, the families' positive support is very important. Lagimodiere and Strachan (2015) stated that athletes who do sports in front of great masses can have a stronger connection with the community due to team environment and they compete not to lose the connection with athletes, coaches or team mates. However, according to the national team athletes in our study, the pressures of the family and the coach that they have to win no matter what and most importantly, the negative cheers by the supporter groups who have come for support have a negative influence on the athlete's moral structure and cause stress, anxiety and as a result emergence of situations which do not comply with fair play. Besides, improper behaviors by individuals who cannot take popularity and success brought by being a national team behavior have a negative effect on the moral structure of the athlete and cause the athletes to develop a negative point of view. While some national team athletes thought that an athlete who knows how to act with experience would have a morally limited effect, some others thought that being a national team athlete or not being a national team athlete does not cause any moral change. It is thought that studies to decrease the pressures of family, friends and supporters on athletes and educating people related with this, creating an environment that the athlete can show top level performance will help the country to be represented in the best way possible.

Athletes who showed a moral attitude towards their rivals during competition stated that they did not reflect the problems between countries to the sports environment; their rival was also a human being and should not be seen on the side of any event. Athletes who showed a moral attitude towards their rivals during competition stated that they were led by a feeling of revenge due to problems between countries in history and the violence their ancestors were exposed to and they could not consider competition only as an activity thus, they could do anything to win. In addition, they stated that the negative pressures of friends and pressures of the coach who put problems with the rival's country to the forefront and want the athlete to win and most importantly the ideological attitude of the rival were effective on the ideological approaches of national team athletes. According to Goodhart and Chataway (1968), sport can also be used in supporting ideology, nationalism, militarism, consumption and injustice about the attitudes of gender, race and disability. In addition, international sport was seen as one of the greatest areas of war in the cold war period and with the thought that superiority in sport competitions represented military superiority, countries invested a lot in sport and athletes (ctd. Donnelly, 2011, p.67-69). Despite these, it is valuable for a great majority of junior national team athletes to show moral attitude without being a part of the ideological superiority race of countries. However, the moral attitudes of the athletes in our study can be resulting from the fact that they have not yet felt the effects of international rivalry and global capital considering their experience in the national team.

Junior national team athletes stated that the expressions of their friends and coaches that competition should be only a sport activity, what matters is to compete, and winning and losing should be considered as normal and the rivals should be approached within the context of fair play motivated them and this positive support had a very big contribution to their moral attitudes towards their rivals. According to Stovitz and Satin (2004), while some sports people view sport only as a game the rules of which should be followed, some others define sport as a war in which the best should be done to win. However, the athletes who do anything to win in the field do not hurt their rivals outside the field. This situation brings to mind that due to the pressures of the environment to win, the athletes do anything to win and try to decrease the pressure on them by winning. In spite of this, the athletes mentioned that the greatest power that motivated them was to wear the national team uniform and represent the country in the best way possible, thus, they should show attitudes proper for a national team athlete, support the image of the country and represent the country in the best way possible.

It was concluded that representing the country in the best way and showing proper behaviors to be a good role model in the society encouraged junior national team athletes and they showed a moral attitude towards their rivals during 
competition. However, we are of the opinion that conducting the research with more experienced athletes who have been on the national team for longer years and researching whether there are any changes in attitudes to rivals as the years of being a national team athlete increase will make contributions to the field.

\section{References}

Allison, L. (2005). The global politics of sport: the role of global institutions in sport. Psychology Press.

Arnaud, P., \& Riordan, J. (Eds.). (2013). Sport and International Politics: Impact of Facism and Communism on Sport. Routledge.

Baş, T., \& Akturan, U. (2013). Nitel araştırma yöntemleri Nvivo ile nitel veri analizi. Ankara: Seçkin Yayıncılık.

Burton, G. (1995). Medya Analizlerine Giriş̧/Görünenden Fazlası (çev. N. Dinç). İstanbul:Alan Yayıncılık.

Danioni, F., Barni, D., \& Rosnati, R. (2017). Transmitting Sport Values: The Importance of Parental Involvement in Children's Sport Activity. Europe's Journal of Psychology, 13(1), 75-92. https://doi.org/10.5964/ejop.v13i1.1265

Donnelly, P. (2011). From war without weapons to sport for development and peace: The Janus-face of sport. SAIS Review of International Affairs, 31(1), 65-76. https://doi.org/10.1353/sais.2011.0015

Firica, J. (2012). Romanian 1dentity representation in Europe by sport as a modern expression of culture in the process of globalization. In Proceedings from the International scientific conference (No. 1, pp. 381-386).

Holmes, M. (1994). Symbols of national identity and sport: The case of the Irish football team, Irish Political Studies, 9(1), 81-98. https://doi.org/10.1080/07907189408406525

Kew, F. (1997). Sport: Social problems and issues. Butterworth-Heinemann An imprint of Elsevier Science Linacre House, Jordan Hill, Oxford, England.

Krüger, A. (1993). On the origin of the notion that sport serves as a means of national representation. History of European Ideas, 16(4-6), 863-869. https://doi.org/10.1016/0191-6599(93)90233-G

Lagimodiere, C., \& Strachan, L. (2015). Exploring the role of sport type and popularity in male sport retırement experiences. Athletic Insight, 7(1), 1-19.

Merriam, B. S. (2013). Nitel araştırma: Desen ve uygulama için bir rehber. (çev. S. Turan). Ankara:Nobel Akademik Yayıncilik.

Stovitz, S. D., \& Satin, D. J. (2004). Ethics and the athlete: why sports are more than a game but less than a war. Clinics in sports medicine, 23(2), 215-225. https://doi.org/10.1016/j.csm.2004.01.002

Talimciler, A. (2005). Türkiye'de Futbol ve İdeoloji İlişkisi: Medyadaki Futbol Söylemi Üzerine Bir İnceleme (yayınlanmamış doktora tezi). İzmir: EÜ Sosyal Bilimler Enstitüsü.

Tomlinson, A., \& Young, C. (2006). National identity and global sports events: Culture, politics, and spectacle in the Olympics and the football World Cup. SUNY Press.

Yıldırım, A., \& Şimşek, H. (2013). Sosyal bilimlerde nitel araştırma yöntemleri. (9. Genişletilmiş Baskı) Ankara: Seçkin Yayıncılık.

\section{Copyrights}

Copyright for this article is retained by the author(s), with first publication rights granted to the journal.

This is an open-access article distributed under the terms and conditions of the Creative Commons Attribution license which permits unrestricted use, distribution, and reproduction in any medium, provided the original work is properly cited. 